\title{
OPERATION OF THE HOUSING OF THE WORKING CLASSES ACT IN IEEDS.
}

\author{
By W. T. LANCASHIRE, A.M.Inst.C.E., \\ City Engineer, Leeds.
}

ABSTRACT.

THIS paper is a sequel to one given by Mr. Geo. F. Carter, A.M.Inst.C.E., 1 at a Congress of the Sanitary Institute in Leeds in 1897.

\section{Part II.-Camp Findd Area.}

Under Part II. the Leeds Corporation dealt with the Camp Field area, where 59 houses were demolished, housing 238 persons, and two large courtyards were formed.

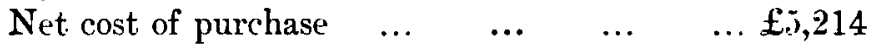

$\begin{array}{lllllll}\text { Cost of works } & \ldots & \ldots & \ldots & \ldots & \ldots & 3,4 \geq 0\end{array}$

$\begin{array}{rlll}\text { Total cost } & \ldots & \ldots & \ldots \frac{£ 8,634}{85} \\ \text { Average price per house } & \ldots & \ldots & \ldots\end{array}$

Cost of improvement per house left in area $\quad \ldots \quad 64$

Do. per house fronting on to new courtyards... 97

Re-housing in connection with Camp Field was provided in 10 houses in Derwent Avenue, each having a living room, scullery, pantry, two bedrooms, and an attic, with conveniences in back yard.

Cost of building, $£ 1,832$. Total cost, $£ 2, \$ 45$.

Rentals 5s. 6id. and 6s. per week, inclusive of rates.

Average number let in 1908, 6.35.

\section{Sanitary Improvements.}

The Corporation have in various parts of the city effected improvements by removing obstructive buildings, though not always under Housing Acts.

During the past 11 years, 421 louses have been demolished, resulting in the improvement of about 1,200 houses, at a cost of $£ 45,000$.

Part I.-York Stieet axd Quakiy Hill Areas.

The confirming Act for York Street area was passed in 1896, and that for Quarry Hill area in 1901. The areas respectively are $16 \frac{1}{4}$ acres and 
50 acres. There were 153 owners in the York Street area, of whom 11 resorted to arbitration, the corresponding figures for the Quarry Hill area are 555 and 24.

The total purchase money paid in York Street area was $£ 191,(000$, and in the Quarry Hill area $£ 565,000$ will have been paid when the purchases are completed.

There were 3,119 persons of the working classes in the York Street area. The Act provided that dwellings should be erected for 2,0001 persons; 1,104 have been re-housed to date by private enterprise according to plans prepared by the Corporation, 906 in cottages at rentals of 5s. $4 \mathrm{~d}$. and 5 s. 6 d. per week inclusive of rates, on an estate within one mile of the area, and 198 persons in tenements within the area at rentals varying from 4s. to 5s. per week, inclusive of rates. These are all consistently well let. In the Quarry Hill area there were 8,618 persons of the workingclasses, and provision was to be made for 6,$000 ; 1,000$ could be dishoused at a first clearance without any housing provision being made.

The Local Government Board has, on the petition of the Corporation, issued two modifying orders in 1906 and 1908 respectively, increasing the number who could be lishoused at a first clearance to 2,000 on the first application, and to 4,000 on the second application.

The available accommodation in unoccupied houses at rentals not exceeding 5s. per week within one mile of the boundary of the two areas increased from 514 houses, or sufficient for 2,570 persons in 1900 , to 1,179 houses, say for 5,895 persons in 1905 , and to 1,987 houses, say for 9,935 persons in 1907. The estimated population of the areas at the last date was 6,176 persons. This increase is probably due to tramway facilities and overbuilding.

In Leeds, 19,111 new buildings were erected from 1900 to 1907 inclusive, providing, at five persons per house, for 95,555 persons, the estimated increase of population for the same period being about 52,500 .

The Corporation have to date, as provision for the Quarry Hill area, provided accommodation in tenement dwellings, erected for them by a contractor, for 108 persons, the rentals varying from $3 \mathrm{~s}$. $6 \mathrm{~d}$. to $4 \mathrm{~s}$. $6 \mathrm{~d}$. per week, inclusive of rates.

Licensed premises have been reduced in York Street area from 15 to 4 , and in the Quarry Hill area from 39 to 5 , three of which have not been acquired by the Corporation. The Corporation have received compensation in the case of 17 .

On the basis of the number of persons displaced, two-thirds of York Street area and one quarter of the Quarry Hill area hare been cleared. 
In the York Street area three streets have been or are being widened to 60 feet, subsidiary streets have been laid out and a number of new buildings have been erected. St. Peter's Burial Ground (disused) is being converted into an open space.

In the Quarry Hill area a portion of a new street, 75 feet wide, has been constructed, and a continuation is in hand: other streets have been widened, and more main thoroughfares are in contemplation. "Loopholing" or the removal of obstructive buildings, and the flagging of open spaces, is being proceeded with in places where immediate wholesale demolition is not contemplated.

Mr. J. Munce (Belfast) referred to the disadvantage under which the discussion was carried on in the absence of printed papers.

He had taken part in the discussion on Mr. Carter's paper on the same subject twelve years ago, and he thought the City Council in their building policy had profited by the criticisms which were then made.

It was a mistake in a city like Leeds, instead of making the area cleared a business centre, to try to fill it up with small houses. With the present facilities for travelling in and ont it was no longer necessary to crowd people into the centre of the city. With their back-to-back houses they were putting too many people on an acre of ground.

He thought the reason why the back-to-back houses in Leeds looked so well was because of the cleanly habits of the people who occupied them, and that they would get a still better condition if they turned the houses round and made through houses of them, getting the advantages of sunlight and pure air.

Aldermax Fraxcis M. Lupton (Leeds) said the question of rent was a very important factor in determining the type of house to be built. Mr. Munce spoke of building houses, and letting them at a loss; but the local authorities could not build nearly all the houses wanted, and even if they could it was surely unfair that the poor dwellers in the houses owned by private persons should pay a part of the rent of those who lived in the houses built by the public authorities.

In order to get sun into every house, streets should, as far as possible, be laid out to run north and south, so that every house should be sunlit either from east or west.

Mr. P. C. Cowax (Chief Engineering Inspector for the Local Government Board for Ireland) said the question was of very great importance and interest. In dealing with it close arguments based on accurate figures were essential, and general statements based on vigue assumptions were useless.

Back-to-back houses could only be defended on their merits; or on considerations of cost.

He could not imagine that anjone in these days, when the value of free air 
and sunshive was so manifest, could defend back-to-back houses on their merits. It appeared to him, as pointed out by Mr. Munce, that satisfactory through houses could be provided on practically the same area of land as back-to-back houses.

$\mathrm{He}$ had worked out the figures, allowing in each case for a street width of 36 feet in front, and in the case of the through house for yards 15 feet deep, and providing in each type for 300 square feet of area of land under the house.

In the back-to-back rows, the total area of land required is $784 \mathrm{feet}$, and in through house, 795 square feet.

It therefore appeared impossible to defend the back-to-back house on the ground of any substantial economy in land.

It should be noted that with back-to-back houses, on account of the extra frontage required, the cost of street-making per house was, at 15s. per square yard, about $£ 36$, whereas with through houses the cost would be about $£ 2210$ s. There was, undoubtedly, some slight saving in walling in back-to-back houses, but it appeared to him that for such slight savings one half of the heavens ought not to be shut off from the workmen's dwellings in Leeds.

$\mathrm{He}$ regretted to observe that small bedrooms with only about 540 cubic feet of space and no vent flues were provided in some of the best new houses for the working classes in Leeds. In Ireland, in a labourer's cottage, the smallest room must have a capacity of at least 600 cubic feet.

He thought the general question might probably await the report of the Local Government Board on the subject, which he understood might soon be issued.

He did not think lineways between back yards were clearly useful. With proper domestic scavenging by the sanitary authority, access to the yard through the house was sufficient, but of course narrow passages from the front or at the rear could be provided to permit convenient drainage and access.

Mr. Fuwis T. HALL (London) felt that one of the most important things they could do was to edncate the working men of this country to copy the cleanly labits of the American workman, who washed himself before leaving work, and did not carry the dust from the factory to his home. If this were done he beliered the evils of tuberculosis would be greatly minimised. $\mathrm{He}$ could not agree that the working man was the best judge of the accommodation he needed, because people used to poor habitations were so conservative that it took them a long time to get used to something better. He was glad to see the: plans for the housing scheme in the city, although he felt it was better, if possible, to take people away from the city. With tramways and other means of locomotion it was better to take people to well planned suburlos. If that were done it would put an end to all discussion as to which was the best type of house for workmen in a city. As to back-to-back houses everyone would admit in principle that a through ventilated house must be better, but the argument appeared to be that the back-to-back house, though not the best, was the best which could be got under the circumstances, having regard to the necessity for 
building in the central area. If that were so, he would make one suggestion. If Leeds bad made up its mind to retain this type of building, then why did they not provide a system of outlet ventiliting gratings in the walls, so that they would always have a current of air going through the house. Mr. Alderman Lupton made a good suggestion when he referred to the rows of houses being planned with an axis north and south. 1t sounded difficult, but in a relaying out scheme it was a thing which could be done. After all it was the sun which was the germ killer, and no matter what might be the conveniences of a house, yet without sunlight they would not have healthy surroundings. In regard to cubic space, he must say his sympathies were with $M$ r. Cowan, and no habitable room ought to be constructed without a ventilating flue.

Dr. A. B. McMaster (Rochdale) asked for particulars of the deatli-rate from tuberculosis in back-to-back houses. In Rocbdale it was higher in houses of this type than in through houses.

Mr. E. G. Mawber (Leicester) illustrated the type of houses built in pairs in Leicester, with a passage between each pair, giving a private yard and garden to each house, facilities for drainage direct to the street sewer, and for removal of refuse.

He objected to long back passages to workmen's houses. The working classes should, where possible, have separate bouses, botl from the point of view of health and of morality.

To provide these advantages in the central parts of a great city like Leeds was a difficult problem, and would probably cost more than working men could pay for in rent.

Providing for the working classes in the surrounding suburbs was sometimes objected to on the ground that the city rates got no benefit from them.

Aldermas Carter (Leeds) said the arrangements proposed by Mr. Cowan and Mr. Mawbey would not be practicable in Leeds.

The Chalruax, in summing up the discussion, and in reply to the remarks in his address, said that Mr. Munce must not blame architects for the designing of either back-to-back houses or small through houses : these were, unfortunately, built without the services of an architect. The portion of the basement of the back-to-back house referred to was used as a washkitchen, not a living room, and answered a good purpose in keeping the steam of washing out of the living room, and lifting the ground floor well up, above the ground or street level.

Mr. Cowan had advocated through houses without back street. In such cases the drainage had to pass under the houses, which was undesirable. Moreover, the whole of the area round the dwellings was not likely to be kept well cleansed.

He agreed that it was desirable to have a flue or fireplace to each sleeping room. 